\title{
Rating Assessment of the Agro-tourism Potential of Rural Areas
}

\author{
Nardin Dmitry Sergeevich, Shumakova Oksana Viktorovna, \\ Binov Oleg Anatolyevich, Novikov Yury Ivanovich, \\ and Nardina Svetlana Aleksandrovna
}

\author{
Omsk State Agrarian University named after P.A. Stolypin, \\ Russian Federation, 644008, Omsk, 2 Institutskaya pl.
}

DOI: http://dx.doi.org/10.13005/bbra/1955

(Received: 03 August 2015; accepted: 17 September 2015)

\begin{abstract}
The main goal of the research is to improve the approaches to determining the agro-tourism potential of rural areas using the method of rating assessment. The methodology of the conducted research involves studying factors and conditions affecting the agro-tourism potential of rural areas and specifying the concept of agro-tourism potential; analysing existing methodologies for the assessment of tourism potential. During the analysis, we revealed weaknesses in existing methodologies and identified the directions for improvement of the approaches to assessing the potential of agro-tourism. Given the identified directions, the original rating assessment method of the agro-tourism potential in rural areas was developed, including the score system of the factors that underpin potential travellers' desire to purchase a proposed agro-tourist product and the factors, contributing to the successful economic implementation of the agro-tourism projects in rural areas. The methodology was tested on the example of the Omsk region municipal districts. With the results of the study, we rated municipal districts of the region by their attractiveness level for the development of agro-tourism and identified priority directions for the development of agro-tourism in the Omsk region. The obtained research results can be used to develop organization models of a regional agro-tourist cluster based on the specialization of certain rural areas in certain areas of the agrotourism development.
\end{abstract}

Key words: Agro-tourism, rating assessment, development directions, region, effectiveness.

Agro-tourism potential of rural areas is a complex socio-economic category, which is a set of interacting factors that contribute to the effective development of agro-tourism. Depending on the conditions that characterize rural areas and the factors influencing their development, they can be assessed and classified in terms of their attractiveness of the agro-tourism development.

Rating assessment can become a classification tool for rural areas based on their agro-tourism potential. The present research is

\footnotetext{
* To whom all correspondence should be addressed.
}

relevant, is of practical value and will be interesting to a wide range of individuals.

Assessment issues of the agro-tourism potential of rural areas are examined in the works of O.N. Barsukova (2012), N.V. Volkova (2015), O.V. Shumakova (2013, 2015), Privalova E.P. (2013), S.A. Hosseini (2015), A.N. Voitekhovuch (2013), M.L. Tenyanskaya (2014) et al. At the same time, the problems of selecting factors and approaches to assessment remain open and require further study and clarification.

The aim of this study is to develop an assessment rating methodology for the agrotourism potential of rural areas. To achieve this goal, the following tasks are supposed to be solved: 
1) Identify factors and conditions which influence the agro-tourism potential of rural areas;

2) Analyse existing methodologies of tourist potential assessment;

3) Determine basic requirements for the rating assessment methodology for the agrotourism potential of rural areas;

4) Develop an assessment rating methodology for the agro-tourism potential of rural areas;

5) Test the developed methodology.

Analysis of the factors and conditions influencing the agro-tourism potential of rural areas should be started by examining the definition of "agro-tourism”, as authors demonstrate various, sometimes diametrically opposite approaches to this concept in scientific publications on this issue. For the purposes of our research, we take the agrotourism as a sector of the tourism industry, which sells various tourist services, aimed at meeting tourists' needs, in rural areas (Nardin, 2009).

Successful implementation of a rural tourism project in a specific rural area depends on the availability of necessary factors and conditions that ensure tourists' interest in the proposed tourism product. In addition, it is necessary to take into account that the agro-tourist activity is essentially an economic activity and requires creating the conditions that allow implementing the project under the terms of economic efficiency (Barsukova, 2012). Thus, the agro-tourism potential of a rural area should be understood not only as the presence of factors that attract potential tourists, but also the level of socio-economic development of rural areas, which has a significant impact on the effectiveness of agro-tourism projects implementation.

Thus, factors affecting the development of agro-tourism potential of rural areas can be divided into two groups.

The first group includes the factors that underpin potential travellers' desire to purchase a proposed agro-tourist product. These factors refer to: 1) unique natural and geological sites located within the boundaries of a rural area; 2) a unique ethnic group and folk crafts in a rural area; 3 ) cultural and historical attractions; 4) ecological well-being of a rural area; 5) agricultural production.

The second group includes the factors that contribute to the successful economic implementation of agro-tourism projects in a rural area, or demonstrate the opportunities for their successful implementation: 1) development of a transport infrastructure, including the overall provision with roads, including paved ones; 2) existing agro-tourism projects - this factor demonstrates a further possibility to successfully realize the agro-tourism potential; 3) developed agricultural production, as an economic base for the implementation of agro-tourism projects (Decree of the Government of the Russian Federation of 31.05.2014 No. 941-p "On approval of the Strategy of tourism development of the Russian Federation for the period up to 2020", 2015).

The assessment methodology for the agro-tourism potential of a region or rural area should take into account the factors from both groups, otherwise the score will be unreasonably overstated or understated, which could equally adversely affect the development of the tourism industry.

\section{Methodology \\ Existing approaches to the assessment of tourism potential}

Currently, the problem of tourism potential assessment at the regional level is actively discussed in the scientific community and is still far from a final solution. This is confirmed by a significant number of diverse approaches to the assessment and methodologies, proposed within the framework of these approaches.

The analysis of existing methodologies to assess the potential of tourist activity showed that all the methodologies are built on the same methodological principle: at the first stage, a range of factors to be assessed is determined. At the second stage, the quantitative and (or) qualitative assessment of selected factors is carried out. At the third stage, the interpretation mechanism for the assessment results is proposed. At the same time, it does not matter which of the areas of tourism activity is assessed.

Thus, Hosseini S.A. (2015) identifies three groups of factors that shape the potential of tourism activity: economic, socio-cultural and ecological. A distinctive feature of this approach is the assessment of the tourism potential by the results that are actually achieved. Interpretation of the assessment results allows singling out the 
areas in which tourism is developed to the greatest extent.

In the works of O.N. Barsukova (2012) it is suggested to carry out the tourism potential assessment taking into account the following factors: availability of tourist resources, availability of an institutional infrastructure, availability of labour resources, availability of related and supporting industries and the presence of demand for tourist services. The method is based on expert assessment of the listed groups of factors. A similar approach to the assessment is reflected in the works of N.V. Volkova et al. (2015). The difference is only in the set of factors that shape the ecotourism potential. Within the framework of the analysis, the authors propose to assess the landscape and recreation, and eco-tourism potential of the area, using experts' evaluation.

The assessment of the tourist potential of areas, based on geographic information systems, which is reflected in the works of E.V. Smirennikova and N.V. Konovalova, is of special note (2011). The essence of the approach is in the division of the area to be assessed into conditional squares and quantitative assessment of these squares by the selected factors. The result is a map of the area in which plots with the highest concentration of favourable factors for the tourism development are highlighted by the colour scheme. The advantage of this approach is visualization that allow identifying potential attraction sites for tourist flows directly on the map. A disadvantage of this approach is the high level of subjectivity of the method, starting with the selection of factors, involved in the assessment and ending with the selection of tools for data processing. In addition, selected conditional plots do not always coincide with the boundaries of certain territories.

The approach of T.A. Tankieva et al. (2014) to the assessment of tourism potential of an area allows putting the economic indicators, generated by the tourism sector, at the front. The methodology presupposes the assessment of objects and events that shape the flow of tourists, as well as factors related to tourist services and awareness of potential tourists about recreational opportunities. The disadvantage of this methodology is in the fact that it is focused on the actual state of the tourism industry in a region, which does not allow assessing potential benefits from the development of new types of tourism.

The closest approach to the assessment of the agro-tourism potential of rural areas is the approach of V.P. Raskovalov (2010), in which the study of natural, historical and cultural, and transport potential, as well as the complex of limiting factors is carried out. Weight coefficients, determined by experts, are assigned to each group of factors. Among the significant disadvantages of the methodology is an expert determination of weight coefficients.

Thus, the existing methods of tourism potential assessment have the following disadvantages: 1) mismatch of the set of indicators with the final assessment goal (to determine the agro-tourism potential); 2) a high level of subjectivity both in defining a set of indicators and in selecting tools for analysis; 3) absence of universality that does not allow comparing areas with different climatic and other factors.

The original methodology of the rating assessment of the agro-tourism potential of rural areas.

The rating assessment methodology of the agro-tourism potential of rural areas must meet the following requirements.

1) The indicators used in the methodology should comprehensively assess the agrotourism potential of rural areas.

2) The methodology should assess the agrotourist potential of rural areas, and allow rating them by the attractiveness for the agro-tourism development based on the integral index.

3) The methodology should enable us to classify rural areas by homogeneous groups and identify priority areas for the development of agro-tourism.

The proposed rating assessment should be universal and enable to assess the agro-tourism potential of rural areas, regardless of their geographic location, socio-economic and climatic conditions. The methodology should allow comparing different rural areas and rate them reasonably.

The methodology includes a set of eight indicators characterizing the agro-tourism potential of rural areas. A score from 0 to 5 is assigned to the first seven indicators, according to their values, and then the calculation of the integral index is 
carried out. The set of indicators and their assessment scale are shown in Table 1.

Calculation of the integral index (I) that characterizes the agro-tourism potential of a rural area is carried out according to the following formula:

$\mathrm{I}=(\mathrm{B} 1+\mathrm{B} 2+\mathrm{B} 3+\mathrm{B} 4+\mathrm{B} 5+\mathrm{B} 6+\mathrm{B} 7) \times \mathrm{B} 8 \quad \ldots(1)$

where $\mathrm{B} 8$ is the indicator, characterizing the presence of a developed agriculture in a rural area. It is determined as a share of agricultural producers located in this rural area, in their total amount in all rural areas, for which rating assessment of agro-tourism development is carried out.

The proposed method was used by the authors to assess the agro-tourism potential and rate rural areas of the Omsk region in terms of the attractiveness of the agro-tourism development.

\section{RESULTS}

The Omsk Region is located in the south of Western Siberia. The territory stretches from north to south for $600 \mathrm{~km}$ and is divided into 32 municipal districts, located in four climatic zones. Northern parts of the region are located in the taiga zone, the southern - in the arid steppe zone (Official site of the territorial body of the state statistics in the Omsk region, 2015). A considerable variety of climatic conditions in the municipal districts, uneven distribution of natural and labour resources, a different development level of

Table 1.The set of indicators of the methodology and their assessment scale

\begin{tabular}{|c|c|c|c|c|}
\hline $\begin{array}{l}\text { S. } \\
\text { No. }\end{array}$ & Indicator & Method for determining & Assessment scale & $\begin{array}{l}\text { Designation of } \\
\text { the indicator's } \\
\text { score }\end{array}$ \\
\hline 1 & $\begin{array}{l}\text { Availability of unique } \\
\text { natural and geological sites }\end{array}$ & $\begin{array}{l}\text { Number of sites located } \\
\text { within a rural area, units }\end{array}$ & $\begin{array}{l}0 \text { units }-0 \text { points; } 1 \text { unit }- \\
1 \text { point; } 2 \text { units }-2 \text { points; }\end{array}$ & B1 \\
\hline 2 & $\begin{array}{l}\text { Availability of cultural } \\
\text { and historical attractions }\end{array}$ & & $\begin{array}{l}3 \text { units }-3 \text { points; } 4 \text { units - } \\
4 \text { points; } 5 \text { and more units }\end{array}$ & B2 \\
\hline 3 & $\begin{array}{l}\text { Availability of a unique } \\
\text { ethnic group and folk crafts }\end{array}$ & $\begin{array}{l}\text { Number of manifestations } \\
\text { within a rural area, units }\end{array}$ & -5 points. & B3 \\
\hline 4 & $\begin{array}{l}\text { Availability of existing } \\
\text { agro-tourism projects }\end{array}$ & $\begin{array}{l}\text { Number of active projects } \\
\text { in a district }\end{array}$ & $\begin{array}{l}0 \text { units }-0 \text { points; } 1-2 \text { units } \\
-1 \text { points; } 3-4 \text { units }-2 \\
\text { points; } 5-9 \text { units }-3 \text { points; } \\
10-20 \text { units }-4 \text { points; } 21 \\
\text { and more units }-5 \text { points. }\end{array}$ & B4 \\
\hline 5 & $\begin{array}{l}\text { Environmental well-being } \\
\text { of a rural area }\end{array}$ & $\begin{array}{l}\text { Amount of pollutants } \\
\text { from stationary sources } \\
\text { that are caught and } \\
\text { neutralized, } \%\end{array}$ & $\begin{array}{l}\text { Up to } 10 \%-0 \text { points, } 10.1- \\
20 \%-1 \text { point; } 20.1-40 \%- \\
2 \text { points; } 40.1-60 \%-3 \\
\text { points; } 60.1-80 \%-4 \\
\text { points; more than } 80 \%-5 \\
\text { points. }\end{array}$ & B5 \\
\hline 6 & $\begin{array}{l}\text { Development of a } \\
\text { transport } \\
\text { infrastructure } 1\end{array}$ & $\begin{array}{l}\text { Provision of local roads, } \\
\mathrm{km} \text { per } 1 \text { sq.km }\end{array}$ & $\begin{array}{l}\text { Up to } 0.04 \mathrm{~km}-0 \text { points; } \\
0.041-0.07 \mathrm{~km}-1 \text { point; } \\
0.071-0.1 \mathrm{~km}-2 \text { points; } \\
0.11-0.14 \mathrm{~km}-3 \text { points; } \\
0.141-0.2 \mathrm{~km}-4 \text { points; } \\
\text { more than } 0.2 \mathrm{~km}-5 \\
\text { points. }\end{array}$ & B6 \\
\hline 7 & $\begin{array}{l}\text { Development of a } \\
\text { transport infrastructure } \\
2\end{array}$ & $\begin{array}{l}\text { Share of local paved roads } \\
\text { in the total length of local } \\
\text { roads, \% }\end{array}$ & $\begin{array}{l}\text { Up to } 10 \%-0 \text { points, } 10.1- \\
20 \%-1 \text { point; } 20.1-40 \%- \\
2 \text { points; } 40.1-60 \%-3 \\
\text { points; } 60.1-80 \%-4 \\
\text { points; more than } 80 \%-5 \\
\text { points }\end{array}$ & B7 \\
\hline
\end{tabular}


Table 2 . Rating of districts in the Omsk region in terms of their attractiveness for the agro-tourism development

\begin{tabular}{|c|c|c|c|c|c|c|c|c|c|c|}
\hline \multirow[t]{2}{*}{$\begin{array}{l}\text { S. } \\
\text { No. }\end{array}$} & \multirow[t]{2}{*}{ District } & \multicolumn{7}{|c|}{$\begin{array}{l}\text { Score of the indicators characterizing the } \\
\text { agro-tourism potential }\end{array}$} & \multirow{2}{*}{$\begin{array}{l}\text { Share of } \\
\text { commodity } \\
\text { producers } \\
\text { B8 }\end{array}$} & \multirow{2}{*}{$\begin{array}{c}\text { Integral } \\
\text { indicator of the } \\
\text { attractiveness } \\
\text { I }\end{array}$} \\
\hline & & B1 & B2 & B3 & B4 & B5 & B6 & B7 & & \\
\hline 1 & Kalachinsky & 3 & 3 & 0 & 0 & 3 & 4 & 3 & 0.101 & 1.616 \\
\hline 2 & Sherbakulsky & 0 & 1 & 0 & 0 & 2 & 4 & 3 & 0.087 & 0.874 \\
\hline 3 & Omsky & 4 & 3 & 0 & 5 & 2 & 5 & 4 & 0.037 & 0.855 \\
\hline 4 & Okoneshnikovsky & 2 & 1 & 0 & 0 & 4 & 3 & 0 & 0.072 & 0.725 \\
\hline 5 & Tavrichesky & 1 & 2 & 0 & 0 & 4 & 3 & 4 & 0.049 & 0.685 \\
\hline 6 & Isilkulsky & 2 & 2 & 1 & 0 & 2 & 4 & 4 & 0.041 & 0.613 \\
\hline 7 & Odessky & 0 & 1 & 1 & 3 & 0 & 2 & 4 & 0.056 & 0.613 \\
\hline 8 & Cherlakovsky & 4 & 2 & 0 & 0 & 2 & 2 & 3 & 0.047 & 0.612 \\
\hline 9 & Kormilovsky & 0 & 2 & 0 & 2 & 5 & 3 & 4 & 0.038 & 0.605 \\
\hline 10 & Novovarshavsky & 4 & 2 & 0 & 2 & 1 & 3 & 3 & 0.033 & 0.493 \\
\hline 11 & Lubinsky & 4 & 1 & 0 & 2 & 2 & 4 & 3 & 0.030 & 0.486 \\
\hline 12 & Poltavsky & 2 & 1 & 0 & 0 & 2 & 3 & 3 & 0.043 & 0.477 \\
\hline 13 & Azovsky & 1 & 1 & 3 & 2 & 1 & 5 & 3 & 0.029 & 0.456 \\
\hline 14 & Moskalensky & 2 & 2 & 0 & 0 & 0 & 4 & 3 & 0.040 & 0.436 \\
\hline 15 & Russko-Polyansky & 0 & 2 & 0 & 0 & 3 & 1 & 3 & 0.046 & 0.413 \\
\hline 16 & Muromtsevsky & 5 & 3 & 2 & 4 & 0 & 1 & 2 & 0.019 & 0.327 \\
\hline 17 & Tyukalinsky & 2 & 1 & 0 & 3 & 4 & 1 & 3 & 0.023 & 0.321 \\
\hline 18 & Bolsherechensky & 2 & 3 & 1 & 3 & 0 & 2 & 4 & 0.019 & 0.279 \\
\hline 19 & Tarsky & 5 & 2 & 1 & 4 & 1 & 1 & 1 & 0.019 & 0.279 \\
\hline 20 & Pavlogradsky & 0 & 1 & 0 & 0 & 2 & 2 & 3 & 0.035 & 0.278 \\
\hline 21 & Nizhneomsky & 1 & 3 & 0 & 0 & 2 & 2 & 3 & 0.025 & 0.273 \\
\hline 22 & Maryanovsky & 0 & 2 & 0 & 0 & 0 & 5 & 3 & 0.027 & 0.266 \\
\hline 23 & Sargatsky & 2 & 2 & 0 & 4 & 3 & 2 & 3 & 0.015 & 0.248 \\
\hline 24 & Gorkovsky & 3 & 0 & 0 & 3 & 0 & 3 & 2 & 0.017 & 0.191 \\
\hline 25 & Znamensky & 3 & 4 & 2 & 2 & 3 & 2 & 4 & 0.009 & 0.173 \\
\hline 26 & Kolosovsky & 1 & 2 & 1 & 3 & 0 & 1 & 2 & 0.012 & 0.124 \\
\hline 27 & Krutinsky & 4 & 2 & 0 & 3 & 0 & 1 & 1 & 0.009 & 0.102 \\
\hline 28 & Bolsheukovsky & 5 & 4 & 1 & 3 & 2 & 0 & 3 & 0.006 & 0.100 \\
\hline 29 & Nazyvaevsky & 2 & 2 & 0 & 2 & 1 & 0 & 2 & 0.008 & 0.072 \\
\hline 30 & Sedelnikovsky & 2 & 3 & 1 & 0 & 0 & 0 & 4 & 0.006 & 0.062 \\
\hline 31 & Tevrizsky & 3 & 5 & 1 & 0 & 0 & 1 & 1 & 0.001 & 0.014 \\
\hline 32 & Ust-Ishimsky & 1 & 3 & 1 & 0 & 0 & 0 & 0 & 0.001 & 0.006 \\
\hline
\end{tabular}

Table 3. Main characteristics of the classification groups in rural areas, depending on the potential directions of agro-tourism development

\begin{tabular}{|c|c|c|c|c|c|c|c|c|c|}
\hline $\begin{array}{l}\text { Classification } \\
\text { group }\end{array}$ & $\begin{array}{c}\text { Unique } \\
\text { natural and } \\
\text { geological } \\
\text { sites }\end{array}$ & $\begin{array}{l}\text { Cultural } \\
\text { and } \\
\text { historical } \\
\text { sights }\end{array}$ & $\begin{array}{l}\text { Unique } \\
\text { ethnic } \\
\text { group } \\
\text { and } \\
\text { folk } \\
\text { crafts }\end{array}$ & $\begin{array}{l}\text { Active } \\
\text { agro- } \\
\text { tourism } \\
\text { projects }\end{array}$ & $\begin{array}{l}\text { Ecological } \\
\text { well-being }\end{array}$ & $\begin{array}{l}\text { The } \\
\text { total } \\
\text { length } \\
\text { of } \\
\text { roads }\end{array}$ & $\begin{array}{l}\text { The } \\
\text { length of } \\
\text { paved } \\
\text { roads }\end{array}$ & $\begin{array}{c}\text { Share of } \\
\text { agricultural } \\
\text { producers }\end{array}$ & $\begin{array}{c}\text { Number } \\
\text { of } \\
\text { districts } \\
\text { in the } \\
\text { group }\end{array}$ \\
\hline 1st group & 22.0 & 19.0 & 5.0 & 18.0 & 10.0 & 11.0 & 15.0 & 12.0 & 6 \\
\hline 2nd group & 20.2 & 13.2 & 1.6 & 12.4 & 17.8 & 16.3 & 18.6 & 28.8 & 9 \\
\hline 3rd group & 12.3 & 18.4 & 7.0 & 12.3 & 7.9 & 17.5 & 24.6 & 31.2 & 10 \\
\hline 4th group & 10.8 & 14.9 & 1.4 & 2.7 & 12.2 & 29.7 & 28.4 & 28.1 & 7 \\
\hline
\end{tabular}


agricultural industries, as well as more than 300 years of the region development led to a variety of factors, determining the agro-tourism potential of rural areas (The tourist portal of the Omsk region “Omsk Irtysh region”, 2015).

The results of the scoring of the agrotourism potential and the rating of municipal districts of the Omsk region in terms of the attractiveness of agro-tourism development are presented in Table 2.

With the use of the methodology, for each of the 32 districts of the Omsk region we gave a numerical score to the indicators characterizing their agro-tourist potential. Based on scoring and a calculated share of agricultural commodity producers, geographically distributed by districts of the region, we calculated the integral indicator of attractiveness. The value of the integral index indicated the presence of potential opportunities for the development of agro-tourism in the region and allowed us to compare different districts by rating them.

The proposed methodology allowed identifying the most promising districts of the Omsk region for the development of agro-tourism. In addition, the method made it possible to determine promising directions of development for each district.

\section{DISCUSSION}

High scores of the first two regions are mainly due to a significant concentration level of agricultural commodity producers in them and a high development level of a transport infrastructure. The priority direction for the development of agro-tourism in these areas is the organization of tours to agricultural enterprises to familiarize urban tourists with features of agrarian production. In addition, for the Kalachinsky district, organization of tourist routes with the visits to unique natural and geological sites, as well as cultural and historical attractions, could become one of the development directions of agro-tourism.

For the Ust-Ishimsky district, which occupies the last place in the rating, the priority directions of agro-tourism development should be linked with the development of tourist routes on the basis of tourists visiting cultural and historical attractions. Thus, one of the major problems that initiators of agro-tourism projects will have to deal with is the low transport accessibility due to the absence of a developed transport infrastructure.

The proposed methodology enabled us to classify rural areas, depending on the potential directions of agro-tourism development, which should be considered as priority ones. The basis of the classification algorithm is the scoring of factors that shape the development potential of agro-tourism in rural areas.

All rural areas that have received one or more maximum scores of "five" by one of the factors, have been referred to the first classification group, those that received the maximum score of "four" - to the second, the maximum score of "three" - to the third group. The fourth group consists of rural areas that received scores of "two" and "one".

Main characteristics of the distinguished classification groups in rural areas are presented in Table 3.

The first classification group includes six municipal districts. A special feature of this group is a low development level of the transport infrastructure and the greatest variety of unique natural and geological sites, as well as cultural and historical attractions, together with a unique ethnic group and folk crafts. This group is also characterized by the most developed sector of the existing tourist projects. The share of agricultural producers, concentrated in the districts of this group is the lowest and amounts to $12 \%$. The priority direction of agro-tourism development is the organization of tourist routes with a focus on the unique nature and history.

The second classification group consists of 9 municipal districts, in which $28.8 \%$ of agricultural producers of the region is concentrated. This group is characterized by a more developed level of the transport infrastructure, the best ecological situation and the availability of a significant number of unique natural and geological sites.

The third classification group is the most numerous and includes 10 districts, in which the largest number of agricultural producers is concentrated (31.2\%). This group is characterized by a high development level of the transport infrastructure and the availability of a significant number of cultural and historical attractions, folk 
crafts and a unique ethnic group.

The fourth classification group consists of 7 municipal districts, on which territory $28 \%$ of agricultural commodity producers of the region is concentrated. This group is characterized by a low concentration of unique natural sites and cultural and historical attractions, as well as by an almost complete absence of active agro-tourism routes, whereas the districts of this group have the most developed transport infrastructure. The priority direction of agro-tourism development for the group is informative agricultural tourism, which includes tourist visits to agricultural production.

\section{CONCLUSION}

In conclusion, it should be noted that the proposed methodology of rating assessment of the agro-tourism potential of rural areas enabled us to classify them according to the potential directions of agro-tourism development, which should be seen as priority ones. The presented classification can potentially become the basis for the development of the organization models of a regional agro-tourist cluster based on the specialization of certain rural areas in certain areas of the agro-tourism development.

A promising direction for further development of the proposed approach to the assessment of the agro-tourism potential of rural areas is the transition from determining the potential directions of agro-tourism development in assessed rural areas to determining performance indicators of tourism activity. The efficiency should be considered from the following positions: efficiency for the initiators of tourism projects, efficiency for the budgets of all levels, efficiency for residents of rural areas and the efficiency for the tourists themselves. The presence of agrotourism potential and the conditions for its implementation for each rural area should be assessed from an economic point of view. Only in this case, it is possible to implement a systematic approach to the sustainable development of rural areas.

The research was conducted with the financial support of RFH. "Organizationaleconomic mechanism of creation and operation of an agro-tourism cluster of the Omsk region”, the project No. 15-12-55011.

\section{REFERENCES:}

1. Barsukova, O.N. and A.K. Buyalskaya, 2012. Marketing Evaluation of Tourist Potential (by the Example of the Tourist Center of Tobolsk). Management of Economic Systems, 8. Date Views 30.07.2015 www.uecs.ru/marketing/item/ 1502-2012-08-22-08-57-48.

2. Volkova, N.V., G.S. Feraru and L.A. Tretyakova, Assessment of the Eco-Tourism Potential of a Region and the Prospects of its Use (by the Example of the Belgorod Region). Regional Economics: Theory and Practice, 2015; 2: 2738.

3. Shumakova, O.V. et al., Methods of Assessing the Potential of Agro-Tourism in Rural Areas. Fundamental Research, 2015; 2(24): 5478-5481. Date Views 04.09.2015 www.rae.ru/fs/pdf/2015/ 2-24/38372.pdf.

4. Nardin, D.S. and N.M. Batskal, Agro-Tourism Place in the Sustainable Development of Rural Areas. Current Problems of Humanities and Natural Sciences, 2011; 4: 99-101.

5. The Official Website of the Territorial Body of the State Statistics in the Omsk Region: The Central Statistical Database. Date Views 30.07.2015 omsk.gks.ru/wps/wcm/connect/ rosstat_ts/omsk/ru/statistics/db/.

6. Privalova, E.P., Comprehensive Assessment of Tourism Potential of the Russian Federation: Regional Aspect. Audit and Financial Analysis, 2013; 3: 427-429.

7. Order of the Government of the Russian Federation No. 941-p of 31.05.2014 "On Approval of the Strategy of Tourism Development in the Russian Federation for the Period until 2020”. Date Views 14.05.2015 government.ru/media/files/41d4e55c9b1d8 bca7b6a.pdf.

8. Tourist Portal of the Omsk Region "Omsk Irtysh Region”. Date Views 30.07.2015 omskturinfo.ru.

9. Hosseini, S.A., Assessment of Sustainable Tourism in Areas with the Highest Tourism Potential with an Emphasis on Social, Economic and Environmental Indicators. Modern Problems of Science and Education, 2015; 1: 1819.

10. Smirennikova, E.V., Factors Affecting the Assessment of Tourism Potential of the Arkhangelsk Region. Bulletin of the Northern (Arctic) Federal University: Humanities, 2009; 4: 23-27.

11. Konovalova, N.V. and E.V. Smirennikova, Assessment of the Tourist Potential of an Area with the Use of Geographic Information 
Methods. Bulletin of the Northern (Arctic) Federal University: Humanities, 2011; 1: 1318.

12. Tankieva, T.A., I.Y. Ponomareva and M.V. Ponomareva, Position-Ranking Assessment Method of a Tourist Attractiveness of an Area. Proceedings of the Tula State University: Economic and Legal Sciences, 2014; 5(1): 174180.

13. Raskovalov, V.P., An Analysis of the Development Potential of the Nature-Oriented Tourism (on the Example of the Perm Region). Geography and Natural Resources, 2010; 3: 132-135.

14. Voitekhovich, A.N. and N.A. Masilevich, Methodological Aspects of the Economic
Assessment of Recreational and Tourist Potential of an Area and Investment in the Tourism Development. Proceedings of BSTU: Economics and Management, 2013; 7: 92-94.

15. Tenyanskaya, M.L., The Use of Statistical Analysis in the Research on Priority Development Directions of the Resort and Recreational, and Tourist Potential of a Region. Economics and Management: Analysis of Trends and Prospects, 2014; 16: 64-69.

16. Shumakova, O.V., O.A. Blinov and M.A. Rabkanova, Formation of an Agro-Tourism Cluster as a Factor of Sustainable Development of Rural Areas. Bulletin of the Altai Science, 2013; 2(2): 192-196. 